\title{
Christian Missionaries and Civilization in Southern Nigeria, 1841-1960: Implications for Contemporary Christians
}

\author{
Kanayo Louis Nwadialor* \\ http://dx.doi.org/10.4314/ujah.v14i2.9
}

Abstract

The history of Christian missionary enterprise in the southern part of Nigeria especially since the nineteenth century reveals the contributions of various missionary bodies to the civilization and development of the area. From the 1840's various Christian missionary bodies have done a lot to evangelize different parts of southern Nigeria, and also had brought about civilization and development of various forms in the area. It is a fact that meaningful missionary enterprise which had yielded enormous result in national development began in the 1840's in Yorubaland (1842), moved to the Efikland by 1846 under the Church of Scotland Mission and then to the Igbo heart land in 1857 spearheaded by the Methodist, the Anglican and the Roman Catholic Churches. This paper has therefore traced the history of the civilizing mission of the various missionary bodies that have been operating in southern Nigeria since the nineteenth century and has highlighted the enormous contributions made by these missionary bodies towards the development and civilization of the area.

\section{Introduction}

The history of Christian mission in the southern part of Nigeria is in essence the story of the development by various Christian denominations and individual missionaries of Thomas Fowell Buxton's doctrine about the civilization of Africa. The well digested plans of Christian philanthropists in England for the 
welfare of Nigeria resulted in the 1841 Niger expedition, having in view the twofold object of striking the slave trade at the root, to introduce industry and legitimate commerce in its place, and of spreading Christianity among the people, as the surest means of elevating Africa in the scale of nations. One of the greatest projectors and master-minds, who framed the plans of that great enterprise with deep foresight and profound thought, (Sir Fowell Buxton), termed the sum total of that which was needed for the benefit of Africa, the Gospel and the Plough - in other words, Christianity and industry. These two words are worthy to be written in letters of gold, and preserved in caskets of silver. According to Ifemesia (1980), consequently, "the British apostles of civilization mobilized all the agencies of civilization- Government agencies, commerce and Christianity into the interiors of West Africa during their civilizing mission in 1841" (p. 87). The role of the Christian missions in the spread of European civilization in southern Nigeria cannot be over-emphasized. It is therefore the task of this paper to highlight the contributions the Christian missions made, especially from the nineteen to the twentieth century towards the development and civilization of the area. It is on record that civilization in Nigeria started around the mission houses. This becomes plain as the importance the Europeans of this age attached to Christianity as a political instrument for furthering the development of commerce and industry is called to mind. It is to be remembered that Christianity had a purifying and humanizing impact on the "pagan" and imperialistic vices and violence of the ancient Roman Empire. To this, Iwe (1985) noted that:

In the dark ages of the $8^{\text {th }}$ and the $9^{\text {th }}$ centuries, Christianity stood singularly firm in the west as the sole symbol of light and guidance and as the pledge of brighter prospect for the future. The rigours of the feudal oppressions, the disabilities 
of the middle Ages and disastrous national rivalries of the era were tempered and alleviated by the stand of Christianity and asylum and succour it provided. (p. 29).

There is no doubt it was Christianity that laid the intellectual and ethical foundation of infant and adolescent Europe. The academies of Rome and Constantinople, the monastic schools of Europe, the early beginnings of University of Bologna, and Paris, Oxford and Cambridge stand to testify. It would therefore not be a wild claim to say that the contributions of Christianity were the historical prerequisites for the European renaissance and for the dawn of the so called age of reason. Furthermore, Iwe (1985) observed that the advent and progress of the industrial revolution did not find the presence of Christianity entirely wanting. It was the forces of Christianity that insisted that the industrial revolution and its institutions should put on a human character and wear a human face. There is also the fact of humanizing and enriching roles and impact of Christianity in the civilizing of nations of such developing regions as Indo-China, South America and so on. There is therefore, an abundance of historical evidence to substantiate the role claim of Christianity as the custodian and promoter of human civilization.

European explorers of the nineteenth century in Africa had revealed the presence in Africa of some commodities of vital importance to European markets. In this regard, Babalola (1988) confirmed that in order to tap these resources of Africa, it was accepted that the Bible should accompany the Plough for the regeneration of Africa. Thus, the missionaries were always asked to accompany European trading missions. "In spite of their pietistic theology, the early missionaries came from a culture which kept only one eye fixed on heaven while the other was focused quite firmly on the earth" (Babalola, 
1988: 205). There were convinced that their missionary ventures could not succeed in a continent where social, economic and political conditions differed considerably from the European type. Thus, they contended that if missionary activities were to succeed, the social, economic and political condition of Africa must first be civilized in European pattern. With this contention, much effort were made by five missionary societies- The Church Missionary Society, the Wesleyan Methodists, the Scotland Presbyterians, the Southern Baptist convention and the Catholic Society of African Mission to encourage the creation in West Africa one or more states in the image of contemporary Europe. All these reechoed the Buxton's doctrine of the Bible and the Plough.

Civilization, for the purpose of this paper refers to the development of southern Nigeria and as such, civilization is used interchangeably with development. To be taken seriously, a definition of civilization/development should embrace connotation of material, social and spiritual advancement. Any civilization lacking these elements is hardly worth the trouble. Against this backdrop, this paper shall present our reflection under the following sub-headings.

(a) Highlights on the local scene before the arrival of the missionaries

(b) Missionaries' concept of civilization in southern Nigeria

(c) Civilizing policies and achievements of the missionaries

(d) Implications for present day Christians

\section{Highlights on the Local Scene before the Arrival of the Missionaries}

It is needful to invite the reader to a picture of the society under review before the advent of the missionaries. This will help the reader to appreciate the efforts the missionaries had 
put forward in ensuring that civilization radiates through the nook and crannies of southern Nigeria. In the early missionary literature, Nigeria and indeed Africa was characterized as one of the universal den of desolation, misery, and crime, and certainly, of all the divisions of the globe it has always had an unfortunate preeminence in degradation, wretchedness and woe (Coleman, 1986). Thus, whereas the non- Christian East was portrayed as having traditions of ancient civilization, Nigeria was believed to have nothing but moral darkness. Much of the country was devastated by various forms of slave trade, Europeans and Arabs, even when the export outlets disappeared, men were still sold into slavery, imposing many distortions in the process, war and kidnapping were rampant in many communities of southern Nigeria as the chief means of getting slaves for sale. Many wars were fought as a reprisal for an act of abduction and sometimes with the intention of obtaining captives. More so the Nigerian society had not become literate. It was perhaps, for such reasons that Rev. Fr. Francis libermann, the pioneer leader of the Holy Ghost Fathers to Nigeria had urged his missionaries to foster civilization (especially education) as well as religion. This was a vision shared by the Anglicans especially Henry Venn, the then honorary secretary of C.M.S. who advocated the course of self-governing, self-propagating and self-sustaining African church, and in this way encouraged the course of civilization in Africa. Jowitt (2010) further confirmed that such policy also enjoyed strong support from the popes of the middle of the nineteenth century, Gregory xvi and Pius ix.

The effect of the work of the missionaries preaching the gospel from village to village and posting their agents to them tended to blunt the sharpest edges of the primitive form of existence that still prevailed in spite of the official abrogation of the slave trade. According to Mgbemene (1996): 
The times were eminently still the era of heathen culture with its concomitants - idolatry, superstition, ignorance, taboos, and bloodshed for serious and trivial causes. Social segregation, disease, famine, malnutrition and many unwarranted practices still held the people in bondage. (p. 393).

In fact the "darkness" of southern Nigeria of the period even after the official abolition of the slave trade was still palpable. Internecine warfare was still the order of the day resulting to loss of lives and wanton destruction of properties. There was utter disregard for human life, culminating in human sacrifice and the cruel practice of burying slaves alive to accompany their dead masters to the other world. Speaking on the extent of human sacrifice in parts of southern Nigerian before the era of the missionaries, Dike (1996) affirmed that the king of Onitsha does not step out of his house into the town unless a human sacrifice is made to propitiate the gods. Until the advent of the missionaries slavery was rampant among the people of southern Nigeria. It was still lucrative to capture and handle slaves; and this was one motive for the frequent intertribal wars. Some of the wars were, as a matter of fact, disguised slave raids. The captives became slaves to be sold, or used for other purposes. "The suppression of the overseas traffic did not lead to prohibition in the interior, and slave dealing continued to exist until the operations became more and more restricted (Basden, 1983:104).

Another institution which portrayed the darkness of southern Nigeria before the arrival of the missionaries was that of $o s u$, cult slavery. The service of a "god" entailed many arduous and difficult conditions, so the service developed into delegating the service to a slave. Henceforward, the slave and his descendants belonged to the "god". The evidence suggests that originally the $o s u$ were regarded with honour and respect. 
In the nineteenth century, their numbers expanded and their status deteriorated dramatically, so that they became outcasts, feared and despised.

The nineteenth century in southern Nigeria was largely the one in which the shadow of darkness overshadowed every aspects of life-the fundamental insecurity, the cheapening of human life, the disintegration of social bonds, the constraint on productivity; how the whole population was continually in a state of excitement and fear, how their fields were neglected, how everyone was afraid of his neighbour-all were the situations in southern Nigeria when the missionaries met them. However, the stand of the missionaries towards these practices has encouraged certain communities to renounce the practices and to declare the practices as no longer existence among their people.

It is left to say that the situation about food and clothing in southern Nigeria before the arrival of the missionaries was described by Crowther as cited in Mgbemene (1996) thus:

When we arrived at Onitsha in 1857 we found the people in a state of idleness, and with its attendants evils, they were scantily and filthily clothed, and in a state bordering on starvation. The introduction of the cassava plants into the country is universally acknowledged as one of the greatest temporal blessing brought to them by their zealous minister. (p. 398).

Its introduction into the diet increased the range of food stuffs available although its nutrient, like that of yam, cocoyam and corn, was carbohydrates; protein-giving foods were lacking, except in the coastal areas where fish and varieties of sea snails and scraps were had. 


\section{Missionaries' Concept of Civilization in Southern Nigeria}

Hunted by the memory that Christianity had once been introduced into West Africa and had been wiped out, the missionaries were anxious to establish a permanent Christian society from where civilization will radiate to the entire Nigerian society. In order to achieve this purpose, a new method of evangelization was formulated - the creation of a middle class of mission educated Africans. According to Ajayi (1965) "the brain behind this policy was Henry Venn, the honorary secretary of the C.M.S" (p. 37). At the time when Venn became secretary of the C.M.S., the abolitionists were embarking on an important change tactics. Hitherto they had sought to achieve abolition mainly by a system of laws and treaties with other European and American countries with little reference to Africa itself. However, "by 1841 they were advocating taking the campaign inside Africa and seeking to regenerate the communities by the Bible and the plough" (Ajayi, 1980:64). That, it was argued, was the only effective way to end the trans-Atlantic slave trade and to make amends to 'down-trodden' Africa for the many wrongs Europe had done her. Further, as the climate was unfavourable to white men, but fortunately there were thousands of liberated Africans in Sierra Leone and emancipated ones in the West Indies and Brazil, mostly professing Christianity, many of them able to read and write, several artisans, school masters, evangelists, who were anxious to return home and whose influence the missionaries could channel towards the reformation of Nigerian society. Such was the background to much of the missionary efforts and ambition of the middle of the nineteenth century.

Missionaries who set out to change a people's religion and beliefs are, by definition, reformers and they must be regarded as developers. In southern Nigeria, missionaries in the nineteenth century sowed seeds of a growth that was to 
yield abundant fruit in the twentieth century. Yet at the beginning of the nineteenth century the idea that such a possibility would be realized must have seemed remote. That the people of southern Nigeria turned out, eventually, to be as receptive to the gospel as it done, and consequently rising into a relatively civilized nation must be counted as one of the miracles of Christian history.

Henry Venn dreamt of missionaries who would engage in ameliorating the social, political and commercial condition of the native tribes, who would advise the local chiefs to respect the principles of law and sound policy. The desire to encourage the growth of an African middle class was the keynote of Venn's policy of development. His desire was that these parties may rise in social position and influence while they are receiving Christian instruction and thus form themselves into a self-supporting Christian Church and give practical proof that godliness has promise of the life that now is as well as of that which is to come (Ajayi, 1980). In the pursuit of this policy, schools were built and qualified teachers were recruited from Europe to bring up the required class. They were not trained only to serve as missionaries; they were to act as guards in leading their own nations to the ideal European standard. Hence they were educated in diverse subjects ranging from Arts, Science, Medicine, and Agriculture to Engineering. To this, Jowitt (2010) confirmed that " the missionaries made some converts and established schools that taught literacy and practical skills; and with the aid of a C.M.S. printing press the first newspaper was published in Yoruba" (p. 222). Nwosu (1988) further noted how "Christian missionary education and evangelism gave rise to missionary involvement in the book industry, marking the beginning of printing and publishing in Nigeria" (p. 47); "the schools taught young Nigerians to aspire to the virtues of white 
Christian civilization" (Coleman, 1986: 114). More so, Henry Venn and his associates sent some Nigerian young men to Europe to be taught European technology. We would be convinced that the purpose of the policy was achieved if we consider the work done by the Nigerians who were thus trained in the European pattern of civilization. For instance, it is on record that the products of the mission schools eventually fought for and secured the political independence of Nigeria.

Again, in the midst of confusion the church had provided stability and order; amid all the hatred it worked for reconciliation, and in all the sorrow it offered comfort. According to Babalola (1988):

The Crowthers (Father and son) together with J.F. Schon and Rev. J. C. Taylor, an Ibo exslave, fought to lead the people of Onitsha, Bonny and other interior places from their human sacrifices and other abominable practices to Christianity and its consequent Western civilization. (p. 207).

The fact that they knew the people, their own tribe's men, made them better received by the native chiefs than the whites. The zeal, determination and good faith with which the Christian missionaries offered their help to down trodden people of southern Nigeria merit some account. Unlike the European traders who tied themselves to the coast and asked the African chiefs to collect for them the commodities of the interior, the missionaries, were prepared to move into the interior themselves. It was this determination of the missionaries to continue their work in southern Nigeria despite the high rate of mortality and native hostility that made them to achieve what the European governments could not. According to Babalola (1988) "in the 1860's and 1870's when native attacks compelled the government and the commercial firms to abandon their posts and desert the Niger, only the missionaries 
remained; obstacles that overwhelmed other groups only inspired the church to greater efforts" (p. 208). No wonder H. Johnson was moved in 1890, as cited in Ayandele (1966) to state that the chief hold which we have over these regions comes from the quite extra- ordinary work done by these four missionary societies-they strengthened our hold over the country, they spread the use of English language, they induct the natives into the least kind of civilization.

Again previous European influences in West Africa were entirely on the basis of trade. Babalola (1983) opines that, it was the missionaries who first established true cultural contact. They lived among the people, visiting their homes sharing their hardship with them, learning their language. The women missionaries, also did some amount of good work in the spread of European civilization among the people of southern Nigerian. These were Mammy Sutherland and Mary Slessor of Calabar, Anna Hinderer of Ibadan, Sarah Townsend of Abeokuta and many others. Apart from their normal work as missionaries, they could enter into intimacy of understanding with mothers of Nigeria and thus imparting to them their European civilization which the mother in turn extended to their children. It is only left to point out that if you educate a man, you educate an individual, but if you educate a woman you educate a family. Furthermore these missionary women acted as mothers to the high number of children whom the slave trade and social upheavals of wars left homeless.

\section{The Civilizing Policies and Achievements of the Missionaries}

The missionary education constitutes their fundamental contribution to the civilization of southern Nigeria. The missionaries were pioneers of education in Nigeria. Akinwumi (1988) asserts that: 
The early schools in Nigeria were funded, managed and staffed by Christian agencies. The primary objective of the missionaries was to convert the people to Christianity through education. The schools were Crowther's principal method of evangelization. All good missionaries made it their duty to convert the children willy-nilly through education. Thus the beginning of education in Nigeria is traceable to Christian missionaries. (p. 60).

In order to convert the unbelievers to Christianity and encourage Christian living among the converts, the missionaries used to organize their converts into congregations for effective teaching. Every congregation was given a school and each unit was taught how to lead Christian lives. In order to do away with interpreters and make their teachings more effective through the use of mother tongue, the missionaries started to study the local languages. Major vernacular languages were put into writing, many schools built by the missions. According to Ifemesia (1978):

They set the local languages-chiefly Efik, Igbo and Ijo-to papers; and prepared primers, lesson books, grammars, vocabularies and dictionaries; and translated prayer books, portions of the Bible and other religious literature. Some adult education was undertaken through Sunday schools and week-day classes for their inquirers and aspirants. (pp. 40-41).

As a result, the local people were able to study the Bible in their own languages and they were made better Christians. Primary schools were opened for teaching the children the Christian religion, English, measurement and simple accounting. In 1895 the C.M.S. founded a training 
institution at Asaba, and the Presbyterians the Hope Waddell Training Institution at Calabar, for producing teachers and evangelists. A unique establishment, Hope Waddell Training Institution had also an industrial and secondary department. It offered courses for boys in carpentry, masonry, coopering, brick making and blacksmithing; for girls in domestic science and dressmaking. Similarly, in 1897, Saint David's Anglican primary school was established at Akure along the above mentioned objective. Also in 1897, the C.M.S. opened an industrial institution at Brass and in 1898 at Onitsha. The men produced by all these institutions were afterwards responsible for spreading the knowledge of the Western arts and crafts they had learned; for erecting many government and mission houses; and for building pews, pulpits, lecterns and other Church furniture in various parts of southern Nigeria.

The usefulness of the missionary education should be underlined. It is to be noted that western education provided the Nigerian people with a lingua franca and tended to increase social communications between the various ethnic groups and also loosened kinship ties. In this regard, Christianity had acted as an integrative force in providing a trans tribal bond uniting individuals of different and formerly hostile traditional communities. Annual church conferences attended by local clergymen and lay agents of diverse cultural background helped to break down parochialism and awakened a wider view and a consciousness of practical identity necessary for the concerted struggles that eventually gave birth to Nigerian independence. Furthermore, missionary education provided the local people with the ideas and values of democracy to be able to attack foreign rule. Also through it they learnt more that they could master their own destiny (Chukwu, 2007). The local people who acquired knowledge of English had access to vast new world of literatures and ideas, and their contact with it 
awakened new aspirations, quickened the urge towards emulation, and accelerated the process of Nigerian civilization.

It was the policy of the missionaries to produce converts who would engage in gainful employment, and be better citizens. To these ends, they encouraged their converts to be better farmers, traders, patriotic citizens and to be interested in the government of their tribes. Boer (2003) noted that in rendering their services the church performed more than just spiritual duties. It fed the hungry, taught farming, carpentry and animal husbandry. This was mainly part of the ideas behind the Christian village system adopted by the Roman Catholic missionaries. St Joseph's Topo established in Badagry in 1876 and the Christian village established in Aguleri were all meant to be the foundations of agricultural establishments for raising the standard of agriculture in the country. In a time when many had lost all things, the church became all things to all men. It became a strong centre around which a people that had lost their direction especially after the civil war could gather and find a new purpose for living. The church prepared men for the life that is to come and preserved civilization for the world that is now is. The converts were made to live near or on the mission stations where they were taught how to live as good Christians.

The school system gave rise to the books-the printing of them, the publishing of them and the selling of them. According to Odudoye (1994):

Printing which was introduced into Nigeria by the C.M.S. in Abeokuta (where Townsend started Iwe Irohin Nigeria's first newspaper) continued in a long-established way at the C.M.S. press, Lagos (and Port Harcourt) while the C.M.S. bookshops combined book publishing and selling in Lagos, Abeokuta, 
Ibadan, Ijebu Ode, Ile-Ife, Ilesa, Akure, Ondo, Owo, Ado-Ekiti and Ikare. (p. 12).

C.M.S. bookshops had the largest chain of book selling retail outlets in southern Nigeria in the nineteenth century and taught many local people the trade. The C.M.S. bookshops pioneered in every branch of the book trade in Nigeria.

Another way through which the missionaries fostered the spirit of civilization in southern Nigeria can be seen in their advice to their converts to obey constituted authorities, pay their taxes and obey the laws of their country, thereby fostering the spirit of civilization among their converts. In this regard, Enweonwu (2010) opines that:

The missionaries inculcated the ideals of Christianity such as sanctity of life, the worth of the individual, the dignity of labour, soul justice, personal integrity, freedom of thought and speech which have been incorporated into the universal declaration of human rights drawn by the United Nation. (p. 15).

Apart from the above, incipient industrialization was becoming increasingly evident in the culture of the people. Some small scale industries such as garri processing industries, saw mills, paint industry, aluminum extrusion plant, paper packaging industry, a few construction and building industries like block molding industries are littered all over southern Nigeria and has been providing increasing employment for the people.

In their determination to provide medical services to the people, the missionaries built hospitals, dispensaries, maternity centres and leper colonies where people were provided with true medical treatment. According to Ozigbo(1988): 
The enormity and frequency of the prevailing sickness the missionaries found impressed them very deeply; their letters and reports are replete with accounts of their medical programme. The prevailing sicknesses at that time were fever, sleeping sickness, cholera, typhus, dysentery, consumption, leprosy, sores and wounds. (pp. 58-59).

The general state of hygiene, nutrition and child-care needed some improvement. The indigenous practice of medicine, as in most societies before the formal application of scientific methods, was largely elementary and magical. The missionary societies demonstrated their interest in medical mission. The C.M.S. established Dobinson Memorial Hospital at Onitsha in 1896, which was later transferred to Iyienu in 1907. It had a ring of village maternities attached to it. At Uburu, the Presbyterians started a hospital in 1915 and leper settlement in 1928. The Methodists built a hospital at Amachara in 1929 and leper colony at Uzuakoli in 1930. The Roman Catholic mission opened St Luke's hospital at Anua in 1933. That year the Roman Catholic mission had six dispensaries and four orphanages in Igboland. The C.M.S. also opened its Oji River Leper Settlement in 1936. In order to solve the problem of shortage of personnel, nursing schools were built where the nurses who were to help in the hospitals were trained.

They also effected rural development by clearing thick forests for the building purposes, treating the sick and the wounded and constructing roads which connected the towns and the various institutions and helped the movement of the farmers and traders in the rural areas. The church has an organization; therefore there could be communication between places distant from each other. 


\section{Implications for Contemporary Christians}

The foundation of American and European civilization is centered in their faith in Christ. American and European missionaries would not have come to Africa at the time they did if the Church and the states of Europe and America were then as poor as African states are today. Therefore, for the Church in Nigeria to make a real impact on the life of the people, it must, as Nmah (2010) suggested, "associate itself with the economic development ideologies of the Nigerian states" (p. 244). The Church pattern of preaching should not be geared towards the condemnation of the people's quest for genuine economic well-being, but rather be concerned with interpretations of the Christian meaning and usage of wealth. The current deplorable economic condition of Nigeria and its consequent unemployment and corruption call not only for the voices of God's people in the church to redress the ills, but also for a direct contribution from the Church to improve the economic condition of the country. In this regard, Nwosu (1998) stated that while it is legitimate to decry the factors that have produced the economic disasters in which Africans find themselves, it is equally appropriate to identify with the various programmes intended to alleviate the economic hardship including participation in economic ventures. The contemporary Church could achieve it by engaging in economic ventures that would produce the required wealth and eliminate poverty, as Nmah (2010) opined:

The post-colonial African states and the third world countries need much more pressingly, today than yesterday the gospel of salvation that must radically take a spiritual and material turn, a turn towards the evolution of the theology of economic liberation. (p. 245). 
Finally, the contemporary Church should engage herself in the promotion of education by investing in building of schools and recruiting qualified teachers to teach in such schools, with proper supervision as did the missionaries in the nineteenth century. Motivational factors such as scholarship to outstanding students should be encouraged. The Church should also identify herself with various programmes of national development. In this way, all hands would be on deck towards the reduction of poverty in Nigeria.

\section{Conclusion}

The missionaries no doubt brought about civilization of various forms to southern Nigeria. They succeeded in teaching useful trade to the natives and their industrial schools have done excellent service in turning out well trained carpenters, coopers, who had no difficulty afterwards in finding employment. They taught trades like brick-making and encouraged agriculture, introducing the planting of rice, improved the traditional cultivation of cotton, and trained a new set of elite that eventually secured the independence of Nigeria, both in the secular and the Church settings. As the gospel of emancipation was being preached, replacing the fear of evil spirits with the love of God in Jesus Christ, the missionaries gave the people good education and opened their eyes to knowledge devoid of superstition. The missionaries also introduced the native tribes of southern Nigeria to scientific medicine, to wholesome eating and living habits, to good sanitation and proper clothing and to refreshing relaxation. They also fostered in them a taste for decent living in all facets of life which today reflects in the people's appearance, their houses, and their diet and in their sense of right and wrong. In rendering these services the church did far more than performing purely spiritual duties but went ahead to engage in the civilization and wellbeing of the people. 
Kanayo Louis Nwadialor is of the Department of Religion and Human Relations, Nnamdi Azikiwe University, Awka.

\section{References}

Ajayi, J.F.A. (1965). Christian missions in Nigeria 1841 1891: The making of new elite. London: Longmans.

Ajayi, J.F.A. (1980). Henry Venn and the policy of development. In. O. U. Kalu (Ed.). The history of Christianity in West Africa (pp. 63-75). London: Longmans.

Akinwumi, M.O. (1988). The contributions of the Church to education, economic and health care services in the southern part of Ondo state. In P.A. Dopamu (Ed.). Religion and development of a nation (pp. 58-70). Ilorin: N.A.S.R.

Ayandale, E.A. (1966). The missionary impact on modern Nigeria 1842-1914: A political and social analysis. London: Longmans.

Babalola, E.O. (1988). Christianity in West Africa: An historical analysis. Ibadan: Book Representation.

Basden, G.T. (1983). Among the Ibos of Nigeria. Lagos: University.

Boer, H.R. (2003). A short history of the early Church. Ibadan: Daystar.

Bosha, B.I. (1988). Ground work of the history and culture of Onitsha. Onitsha: Ifechukwu.

Chukwu, D.O. (2007). An introduction to Nigerian political history. Enugu: His Glory.

Coleman, J.S. (1986). Nigerian background to nationalism. Benin: Broburg \& Wistrom. 
Dike, K.O. (1996). Origins of the Niger mission 1841-1891. In S.N. Adiele (Ed.). The Niger mission: Origin, growth and impact (pp. 294-319). Aba: Isaeco.

Enweonwu, P.O. (2010). Advent and impact of Christianity in Onitsha: A distinct community of Igbo sorority. Onitsha: Redeemer Link.

Ifemesia, C.C. (1980). The civilizing mission of 1841. Aspect of an episode in Anglo - Nigerian relations. In O.U. Kalu (Ed.). The history of Christianity in West Africa (pp. 81 -101). London: Longmans.

Ifemesia, C.C. (1978). Southeastern Nigeria in the nineteenth century: An introductory analysis. New York: Nok.

Iwe, N.S.S. (1985). Christianity and culture in Africa. Onitsha: University.

Jowitt, D. (2010). Christianity: A concise history. Ibadan: Kraft.

Mgbemene, A.E.D. (1996). Effect of the Anglican Churches in the life of the people in the eastern states of Nigeria. In. S.N. Adiele (Ed.). The Niger mission: Origin, growths and impact (pp. 380-422). Aba: Isaeco.

Nmah, P.E. (2010). Christian missions and socio-economic development in colonial West Africa 1841-1960: A challenge to global evangelism in the third millennium. In A.B.C. Chiegboka, T.C. Utoh-Ezeajugh \& G.I. Udechukwu (Eds.). The humanities and globalization in the third millennium (pp.240-247). Nimo: Rex Charles and Patrick.

Nwosu, D.C. (1988). Religion and development: The educational perspective. In P.A. Dopamu (Ed.). Religion and development of a nation (pp. 41-57). Ilorin: N.A.S.R.

Nwosu, L.U. (1998). The religious factors in the history of West Africa. Owerri: Vivian \& Vivians. 
Ododuye, M. (1994). The church in Yorubaland 1842-1992. In A. Omoyajowo (Ed.). The Anglican Church in Nigeria 1842-1992 (pp. 1-16). Lagos: Macmillan.

Ozigbo, I.R.A. (1988). Roman Catholicism in southeastern Nigeria 1885-1931. Onitsha: Etukokwu. 